\title{
SECURITIES REGULATION: INSIDER STATUS IN LEGAL FICTION AND FINANCIAL FACT-A PROPOSED REVISION TO SECTION 16(b)
}

On August 5, 1954, Joseph Thomas, a partner of the Lehman Brothers investment banking firm, replaced another Lehman partner on the board of directors of the Tidewater Associated Oil Company. On October 8, 1954, Tidewater publicly announced an option to convert its common to a new cumulative preferred. In the following five months, Lehman Brothers purchased 50,000 shares of Tidewater common, exercised the option to convert the common to the new cumulative preferred, and sold the preferred. On behalf of Tidewater, a stockholder sued Thomas and Lehman Brothers under section 16(b) of the Securities Exchange Act of $1934^{1}$ to recover the profit realized by Lehman Brothers on these transactions. In Blau v. Lehman, ${ }^{2}$ the United States Supreme Court held that Thomas was liable only to the extent of his proportionate interest in the partnership profits and that his directorship did not subject the Lehman Brothers partnership to the liability imposed upon corporate insiders by section 16(b). Although the Court implied that partnership liability might result from either the actual use of inside information or the deputation of a partner-director to represent the partnership on the board, ${ }^{3}$ the practical effect of this decision is to immunize a director's

148 Stat. 896 (1934), 15 U.S.C. $\$ 78$ p(b) (1958). Section 16(b) provides in part:

For the purpose of preventing the unfair use of information which may have been obtained by such beneficial owner, director, or officer by reason of his relationship to the issuer, any profit realized by him from any purchase and sale, or any sale and purchase, of any security of such issuer (other than an exempted security) within any period of less than six months ... shall inure to and be recoverable by the issuer ....

See generally Loss, Securities Regulation (2d ed. 1961); Cole, Insiders Liabilities under the Securities Exchange Act of 1934, 12 Sw. L.J. 147 (1958); Cook \& Feldman, Insider Trading under the Securities Exchange Act, 66 HaRv. L. Rev. 385, 612 (1953); Meeker \& Cooney, The Problems of Definition in Determining Insider Liabilities ander Section 16(b), 45 VA. L. REv. 949 (1949); Rubi \& Feldman, Statutory Inhibitions ufion Unfair Use of Corporate Informalion by Insiders, 95 U. PA. L. REv. 468 (1947).

2368 U.S. 403 (1962). The Chief Justice concurred in a dissent by Mr. Justice Douglas. The court of appeals decision, Blau v. Lehunan, $286 \mathrm{~F} .2 \mathrm{~d} 786$ (2d Cir. 1960), is noted at 61 Colum. L. Rev. 926 (1961), 30 FordhaM L. Rev. 178 (1961), 49 Geo. L.J. 779 (1961), 14 Stan. L. Rev. 192 (1961).

3 The concept of deputation originated in a dictum by Judge Learned Hand in Rattner v. Lchman, 193 F.2d 564 (2d Cir. 1952) (concurring opinion), the only other case to consider partnership hability under $\$ 16(\mathrm{~b})$. The court of appeals in the Blan case disapproved the deputation test. 286 F.2d at 789.

It would seem that the non-director partners need not be troubled by the threat of a lone shareholder proving deputation. If neither the principles of partnership law (N.Y. PARTNERSHIP LAw § 20(1) provides, "Every partner is an agent of the partnership for the purpose of its business.") nor the acquisition of over 100 directorships is sufficient to establish "deputation," then the term is either meaningless or without application to the facts of financial hife.

The unreliability of the deputation concept is evidenced by the disparate interpretations of the same facts by different judges. The district court in the Blau case excluded plaintiff's evidence of the systematic and deliberate acquisition of directorships by Lehman Bros. in order to further its own interests. Brief for Petitioner, pp. 24-25, Blau v. Lehman, 368 U.S. 403 (1962). The court then found "no evidence that the firm of Lehman Bros. deputed Thomas to represent its interests on the board ...." Blau v. Lehman, 173 F. Supp. 590, 593 (S.D.N.Y. 1959). (Emphasis added.) On appeal Judges Medina and Swan found "no evidence of any deputizing or other affirmative action by the firm to cause Thomas to be made a director to protect the interests of the firm or to become its representative." 286 F.2d at 789. (Emphasis added.) 
partners from liability for profits derived from the partnership's speculation in the securities of his corporation. ${ }^{4}$

This comment is an attempt to evaluate the wisdom of allowing trading partnerships to profit by speculating in the securities of corporations of which a partner is a director. Part I describes the economic functions performed by the investment banking system. Part II, supplemented by the Appendix listing some of the directorships lield by Lehman partners and the directors of Lehman Corporation, examines the access to inside information, the financial power, and the potentially incompatible fiduciary relationships that result when one firm simultaneously performs all of the economic functions described in part I. ${ }^{5}$ Part III examines busmess ethics in order to determme whether the necessary self-restraint of corporate insiders is sufficiently viable and common to protect the investing public. The conclusion proposes that section 16 (b) be amended to make it responsive to some of the problems raised in parts II and III without frustrating the constructive economic functions performed by the investment banking system or unnecessarily restricting the financial freedom of the men who operate that system.

The primary economic function of investment banking is to facilitate capital formation. Capital formation is the development of facilities to produce and market consumer goods; it is essential to both the adaptability of mature economies and the development of underdeveloped economies. ${ }^{6}$ The two major external sources of capital for industry are the investment and commercial banking systems. The forms of capital supplied to industry by the commercial banker and the investment banker are as fundamentally different as the two systems that generate them. The commercial banker supplies industry with capital in the form of short term loans with a fixed interest and maturity. The investment banker provides industry with equity capital and long term loan funds through the underwriting and distributing of corporate securities.

Judge Clark, dissenting, stated, "Here the evidence of director-participation is rather sharper than Judge Medina intimates and goes so far that it is hard to see what more the director could have done to assist his partners short of doing the trading himself." $286 \mathrm{~F} .2 \mathrm{~d}$ at 795. Reviewing the findings below, the Supreme Court stated, "Inferences could perhaps have been drawn from the evidence to support petitioner's charges, but examination of the record makes it clear to us that the findings of the two courts below were not clearly erroneous." 368 U.S. at 408-09. (Emphasis added.) Compare the application of partnership law to partner-directors in Lehman v. CAB, 209 F.2d 289 (D.C. Cir. 1953).

4 "What we do today allows all but one partner to share in the feast which the one places on the partnership table. They in turn can offer feasts to him in the 99 other compamies of whieh they are directors." Blau v. Lehman, 368 U.S. 403, 420 (1962) (Douglas, J., dissenting).

5 See House Select Committee on Small Busmess, Interlocking Directors and Officials of 135 Large Financial Companies of the United States, H.R. REP. No. 1278, 85th Cong., 1st Sess. (1957), for a thorough description of the interlocking relationships among the 135 largest financial firms.

- See Bogen, Economics of Investment Banking, in Investarent Bankers Association of AMierica, Fundamientals of Investment Banking 3 (1947); see generally ChILds, Long-term Financing (1961). The estimated gross proceeds from new securities offered for cash in the United States during the period Jan.-Nov. 1961, totaled $\$ 33,269,209,000$, of which securities $\$ 11,936,922,000$ were corporate and $\$ 21,332,287,000$ were noncorporate. The proposed uses of the proceeds from these corporate offerings were new money, $\$ 9,807,336,000$ (of the new money $\$ 6,930,842,000$ was for plant and equipment and $\$ 2,876,495,000$ was for working capital), retirement of securities, $\$ 827,608,000$, and other purposes, $\$ 1,050,924,000$. SEC STATISTICAL Burr. 13, 15 (Jan. 1962). 
Both the commercial banker and the investment banker solicit funds from the public, thus competing for the utilization of idle capital and the reallocation of existing investment capital. The commercial banker receives money in the form of deposits that he reinvests for his own account at a higher rate than that returned to the depositor. The investment banker receives money by selling corporate securities. ${ }^{7}$ He usually does not invest his own money in a new issue but rather provides the formal, organized system through which others may invest in the new issue. He assures the issuer of capital either by purchasing the entire issue outright or by obligating himself to purchase whatever part of the issue he is unable to sell to the ultimate investors by a certain date. ${ }^{8}$ His profit is derived from the "spread," i.e., the difference between the price per share he pays to the issuer and the price per share lie receives from the the ultimate investors. The spread involves recompense for managerial services, retailing, risk, and out of pocket costs. ${ }^{9}$

Two main combinations, the purchase group and the selling group, are involved in underwriting and distributing corporate securities. The purchase group is composed of the "manager" or "originator" of the issue and, if the issue is sufficiently large to necessitate spreading the risk of the venture, various wholesalers associated with hin. The originator is usually an investment banking firm that maintanis continued contact with corporations needing new money. ${ }^{10}$ The wholesalers associated with him in the purchase group are other firms that originate

7 The Banking Act of 1933, ch. 89, 48 Stat. 162 (1933) (codified in scattered sections of 12,39 U.S.C.), separated commercial from investmetnt banking by prohihiting commercial banks from underwriting securities and investunent banking firms from accepting deposits.

8 Even under an outright purchase agrecment the investment banker acts as a conduit rather than as an investor. This is because the investment banker does not pay the issuer until the closing date of the issue; by that time the investment banker has usually retailed the entire issue.

9 For example, in the initial public offering of Ford stock the spread was allocated as folows: management fee $\$ .10$; selling fee $\$ 1.00$; risk $\$ .30$; out of pocket costs $\$ .10$. As the following chart of the average flotation cost of registered corporate securities for 1951, 1953, and 1955 illustrates, the size of the spread varies with the amount of the issuc.

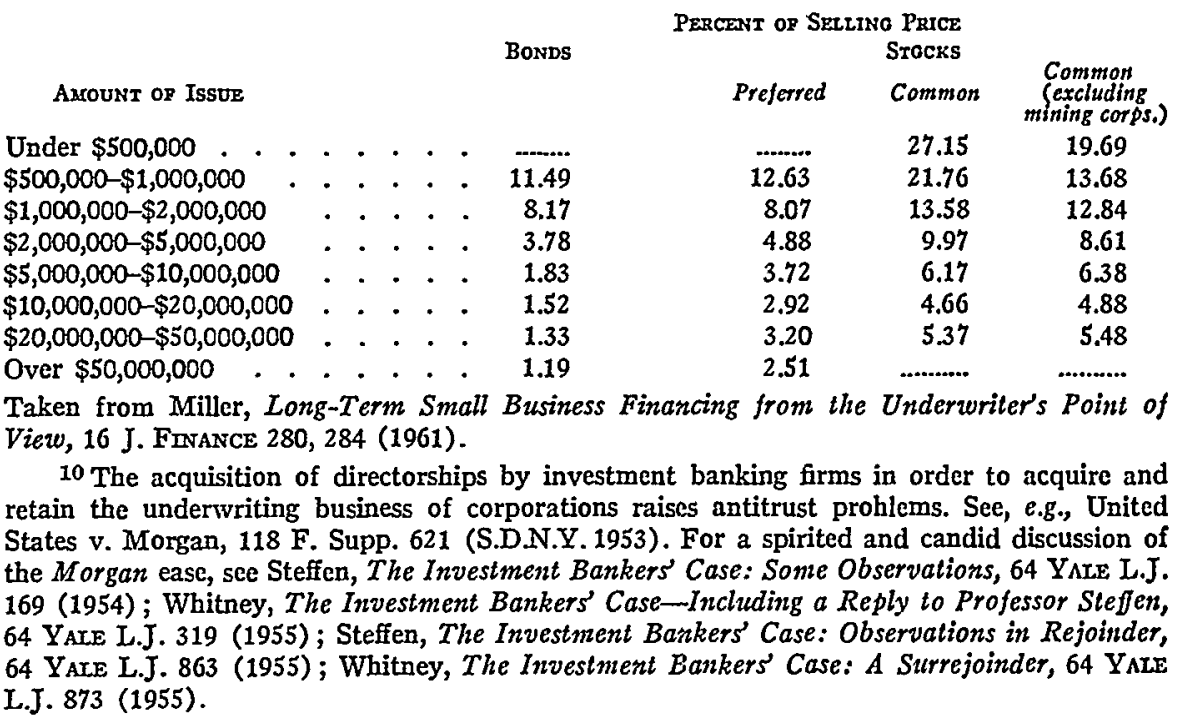


as well as firms that specialize in distribution. Each member of the purchase group assumes responsibility for the disposal of a certain portion of the new issue.

The originator is responsible for settmg up and underwriting the entire issue and contracts with the issuer on behalf of the entire purchase group. The originator must evaluate the issuing corporation and the industry in which the issuer is engaged and correlate the financial objectives of the issuer to the securities market. The originator then sets up the issue, negotiates the spread, and if the issue is a large one, organizes the underwriting and distributing syndicate.

The selling group is the link between the purchase group and the ultimate investor. It is composed of firms that specialize in retailing as well as firms that retail incident to conducting a general brokerage business. A retailer may act as a broker, an agent wlio purchases and sells for a principal and is compensated by a commission, or as a dealer, a principal who purchases and sells for his own account and is compensated by the price differential. As dealer or broker, a retailer may purcliase or sell in an auction market, e.g., the New York Stock Exchange, or a negotiated market, e.g., the over-the-counter market. ${ }^{11}$

In addition to his primary function of facilitating capital formation the investment banker performs numerous secondary functions. He acts as a financial advisor and investment counsellor to corporations whose principal business is other than investing in securities, to investment companies, and to individual clients. He will assist in corporate mergers, acquisitions, and consolidations, activities that may require anything from a simple purchase of shares on the market to complex exchanges of various classes of publicly lield securities. The mvestment banker's financial acumen and knowledge of corporations, industry, and the securities market qualifies him to establish fair ratios for such exchanges of securities.

Finally, the investment banker engages in entrepreneurial activities for his own account, which may take the form of "lock-up" transactions involving the discovery and development of business opportunities. ${ }^{12} \mathrm{He}$ also participates in the securities market for his own mdividual account and for that of his firm. This may take the form of arbitrage, ${ }^{13}$ investment, or speculation. It was the latter type of transaction tliat was questioned in the Blau case.

11 "The term over-the-counter market is a misnomer. So are the expressions unlisted market. and offboard market. All apply to the same thing: the processes, places and people involved in all securities transactions that take place without benefit of the facilities of an organized stock exchange." Trigger, The Over-the-Counter Market, in Investanent Bankers Association of AMIERICA, Fundastentals of InVestament Banking 537 (1947).

12 A good example of a "lock up" transaction is Lehman Bros.' purchase of the Jergins Corporation, a family controlled oil company, for $\$ 29,000,000$, the following account of which is taken from Wise, The Bustling House of Lehman, Fortune, Dec. 1957, p. 186. Lehman Bros. raised the $\$ 29,000,000$ purchase price by borrowing $\$ 19,000,000$ from the Chase Manhattan Bank and by obtaining a total of $\$ 10,000,000$ from the partnership itself, Lehman Corp., other corporations, e.g., CIT Financial Corp., and other investment banking firms. Lehman Bros. renamed the corporation "Monterey Oil" and, within two years, caused it to sell: (1) an office building: (2) a gasoline plant; (3) a minority interest in an electronics firm (Beckman Instruments) for $\$ 10,000,000$, of which $\$ 5,000,000$ was returned to the investors and $\$ 5,000,000$ went to reduce the bank loan to $\$ 14,000,000$; and (4) its interest in the San Ardo oil field for $\$ 18$,200,000 , of which $\$ 14,000,000$ closed the bank loan and $\$ 4,200,000$ was returned to the investors. This left Monterey Oil (now liquidating) with assets remaining worth $\$ 28,000,000$. Thus, within two years, the investors were returned $\$ 38,000,000$ on a $\$ 10,000,000$ investment. See also MAYER, WAII STREET: MEN AND MONEY 220 (1955).

13 "Arbitrage" is either the purchase and sale of the same security in different markets at different prices, or the purchase of a security exchangeable for another security and a sale of the second security in order to profit from the disparity in the prices of the two securities. 
The economic inplications of allowing an insider's partners to speculate in the securities of his corporation can be demonstrated by examining the activities of a large investment banking firn. The financial relationships and operations of Lehman Brothers are typical of large investment banking firms and illustrate the probleins that result when each of these firms simultaneously performs all of the economic functions described in part $\mathrm{I}^{14}$ The directorships held by Lehman partners ${ }^{15}$ and by the directors of Lehman Corporation, a closed-end inanagement investınent company originated and controlled by Lehman Brothers, ${ }^{10}$ may be summarized as follows: the 24 Lehman partners hold 82 directorships in 69 corporations with total assets of $\$ 21,335,555,000$; the 21 directors of Lehman Corporation hold a total of 131 directorships in 97 corporations with total assets of $\$ 88$, 439,779,000; the Lehman partners and the directors of Lehman Corporation hold a combined total of 167 directorships in 128 corporations with total assets of $\$ 100,642,148,000$. More than one half of this figure represents the assets of other financial institutions such as banks, insurance companies, and other investment companies. ${ }^{17}$ This centralization of important directorships concentrates in one

14 For an interesting and informative article, see Wise, The Bustling House of Lehman, Fortune, Dec. 1957, p. 157. See also House Select Committee on Small Business, Interlocking Directors and Officials of 135 Large Financial Companies of the United States, H.R. REP. No. 1278, 85th Cong., 1st Sess. (1957). This report demonstrates that the appetite for directorships evidenced by Lehman Bros. is typical of other large financial firms. Thus, "of the 135 largc financial companies making up the 'base' companies of the report, 107 [79\%] had 1 or more interlocking connections with 1 or more of the other 135 base companies. ... The same 'base' companies have been shown to have interlocking connections with 901 , or 55 percent, of the 1,642 other companies in the study." Id. at XVIrI.

15 "The Commission's public records disclose that the 23 partners of Lehman Brothers hold over 100 directorships (SEC File No. 801-364), many of which are in companies registered on national securities exchanges." Brief for the SEC as Amicus Curine, p. 8, Blau v. Lehman, 368 U.S. 403 (1962). The Appendix to this comment does not include directorships held in corporations not listed in Standard \& Poor's Corp., Standard Corporation Descriptions (1961) or Moody's Investors Service, Moody's Bank \& Finance Manuat (1961), nor does it include subsidiaries controlled by corporations that are listed in the Appendix.

16 Eight of the twenty-one directors of Lehman Corp. are Lehman partners. Lehman Bros. has a management contract with Lehman Corp. whereby Lehman Bros. "advises on the purchase and sale of portfolio securities, gives overall direction to the Corporation's operations and places the facilities of its large organization at the disposal of the Corporation at all times." [1961] LemMan CoRp. ANn. Rep. 4.

17 See the Appendix. As to the scope of the Appendix, see note 15 supra. One hundred billion dollars is approximately six times the gold reserves of the United States Treasury; five times the total of all taxes collected by all of the states from all sources in 1960; equal to the total of the assessed valuation of property in California, Illinois, Michigan, and New York; and, over one third of the total of the assessed valuation of property in all of the states. See 28 Tax Policy 10 (Oct. 1961) ; Tax Foundation, Inc., Facts and Figures on Government Finance (10th ed. 1958-1959).

On the concentration of economic power in the United States, see BERLE \& MEANs, Trie Modern Corporation and Prtvate Property (1932); Lamler, Concentration of Control in AMertcan Industry (1931); Lassweti. \& Kaplan, Power and Soctety (1950); Muls, The Power Elite (1956); NutTer, The Extent of ENTERPrise Moncpoly IN THE UNITED States, 1899-1939 (1951); House Select Committee on Small Business, Interlocking Directors and Officials of 135 Large Financial Companies of the United States, supra note 14; TNEC, Investigation of Concentration of Economic Power, S. Doc. No. 35, 77th Cong., 1st Sess. (1941); Adelman, The Measurement of Industrial Concentration, 33 REv. Economics \& STaTISTICS 269 (1951); Berle, The Developing Law of Corporate Concentration, 19 U. CHr. L. REv. 639 (1952). For a recent evaluation of Berde \& Means, The Modern Corporation and Private Property (1932), see Manne, The "Higher Criticism" of the Modern Corporation, 62 Colvur. L. REv. 399 (1962) and the reply of Professor Berle, Modern Functions of the Corporate System, 62 ColuM. L. REv. 433 (1962). 
group of men: (1) maximum access to inside information, (2) maximum power to use inside information in màrket activities, and (3) numerous incompatible fiduciary relationships. The effects of this concentration will be discussed in the following paragraphs.

The partners of Lehman Brothers have access to the inside information of the more than one hundred corporations of which they are directors as well as to the inside information of the numerous other corporations for which they have acted as underwriters, investment advisers, or management consultants. In addition, each of the eight partner-directors of Lehman Corporation may benefit from the knowledge that the thirteen nonpartner-directors derive from their seventy-two other directorships..$^{18}$ Lehman Brothers and Lehman Corporation also maintain large, competent research and analysis staffs that collect and evaluate corporate information. ${ }^{19}$ Finally, there is circulation of inside information among the partners themselves incident to their activities as directors and advisors to industry. ${ }^{20}$

Coupled with the origination, collection, evaluation, and circulation of inside information is the power to use that information effectively in market activities. Lehman Brothers directly controls the investment of approximately two billion

18 This possibility results from the duty of the directors of Lehman Corp. to disclose all information pertinent to managing the Lehman Corp. portfolio. However, the duty to speak is opposed by the incompatible duty not to disclose the confidential information of the other corporations of which they are directors.

It is arguable that the directors' duty not to disclose the inside information of the other corporations of which they are directors is a prior disability which the investors in Lehman Corp. accept, thus negating the incompatible duty to Lehman Corp. On the duties of directors of mutual funds, compare Lobell, Rights and Responsibilities in the Mutual Fund, 70 YarE L.J. 1258 (1961), with Comment, The Mutual Fund and its Management Company: An Analysis of Business Incest, 71 Yare L.J. 137 (1961). See generally Eisenberg \& Phillips, Mutual Fund Litigation-New Frontiers for the Investment Company Act, 62 Colum. L. Rev. 73 (1962).

19 Basic to the investment advisory services of Lehman Brothers is the work of its Economics Department .... The department, one of the largest in any Wall Street firm, is concerned with making judginents as to the likely course of the economy not only over the next year or two but for the longer term as well. ... The economist's decisions are based partly upon the study of statistical records. . . . In addition, a high level of personal interchange is maintained with leaders in business and government. ... From such discussions come adjustments in published reports, a sharpening of estimates and a clearer focus upon essentials.

[1961] The One Williadr Street Fund, Inc. AnN. Rep. 8. (Einphasis added.)

On the average, Lehman Brothers analysts spend about one guarter of their time on field trips in order to talk with top corporate officials in the United States and abroad. Sueh visits establish and develop favorable relationships. These contacts are of great value in the constant search for facts required to make investment recommendations.

[1961] The One Winlitar Street Fund, Inc. Ann Rep. 9. (Emphasis added.)

In the Annual Report of the One William Street Fund, the favorable relationships enjoyed by Lehman Bros., as well as the practical utilization of those relationships, is conveyed by a photograph of a member of the Investment Advisory Service, the financial vice president of the Bristol-Myers Company, and a Lehman partner "discussing new developments." "At yearend, The Fund held 100,000 shares of Bristol-Myers Company with a market value of $\$ 9.1$ million." Ibid. Thus, Lehınan Bros. both enjoys and advertises access to inside information.

20 At these Monday Lunehes the partners are also likely to discuss a variety of problems confronting the corporations on whose boards they serve. The main question at a recent meeting was whether several security issues should be postponed in view of tumbling stock prices. There was discussion, too, of whether a nlanufacturing company whose profits were declining should cut its dividend.

Wise, The Bustling House of Lehman, Fortune, Dec. 1957, p. 159. 
dollars, ${ }^{21}$ and through directorships indirectly influences the financial policies of sixty-nine corporations with total assets exceeding twenty billion dollars. ${ }^{22}$

The partners of one firm simultaneously acting as underwriters, brokers, dealers, investment counsellors, management consultants, professional directors, and general entrepreneurs are inevitably faced with pervasive conflicts of interest. ${ }^{23}$ Thus, as the investment manager of Lehman Corporation, Lehman Brothers has a duty to inanage its portfolio efficiently. But as broker to Lehman Corporation, the interest of Lehman Brothers is to keep the account active. ${ }^{24}$ As director of the One William Street Fund, Inc., an open-end management investment company originated and controlled by Leliman Brothers, ${ }^{25}$ the partner-director's duty is to obtain competent investment management as cheaply as possible. But as a Lehman partner and investment manager of One William Street, the partnerdirector has a duty to the partnership to obtam as high a management fee as possible. Thus, as a Lehman partner he requests, and as a One William Street director he approves, a certain nranagement fee. ${ }^{26}$

When one man simultaneously represents the underwriter, the issuer, and the ultimate investor, he is subject to incompatible fiduciary duties. The partner's duty to his partnership is to negotiate as high a spread as possible. The director's duty to his corporation is to assure it a maximum net return on a new issue. The partner-director's duty to Lehman Corporation is to supervise its portfolio. Thus, the Lehman partner as Lehman partner requests, and as director of the issuer

21 The sources and means of control are:

Lehman Corporation . . . .

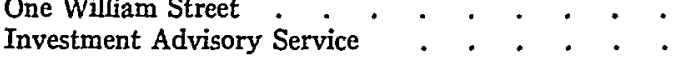

Partnership portfoho \& personal wealth of partners

$\$ 353,812,000$
$294,102,000$
$1,000,000,000$ (estimated)
$500,000,000$ (estimated)

$\$ 2,147,914,000$

Thus, Lehman Brothers controls directly the investment of more money than the assessed valuation of property in each of the following states: Arizona, Arkansas, Delaware, Georgia, Maine, Mississippi, Montana, Nebraska, New Hampshire, New Mexico, North Dakota, South Carolina, South Dakota, Utah, Vermont, and Wyoming. See TAX Foundation, INC., FACTS AND FiourEs on GovernMENT FINANCE (10th ed. 1958-1959).

22 This approximately equals the assessed valuation of property in California. Although the partner-director has only one vote, his advice and recommendations on financial matters would be especially persuasive since he controls, as a Lehınan partner, a significant source of capital, and is an expert on matters of corporate finance. In some corporations, Lehman partners bold offices in addition to their directorships; e.g., one Lehman partner is a member of the executive committee of Paramount Pictures, Inc. and another Lehman partner is a member of the executive and financial committees of the Twentieth Century Fox Corp. Sce Appendix.

23 On shareholder acceptance of prior disabilities, see note 18 sippra.

24 Lehman Bros. received $\$ 225,000$ for management services and $\$ 482,979$ in brokerage commissions from Lehman Corporation in 1961. [1961] LEmanan CoRp. Alsw. Rep.

25 See note 26 infra.

26 In 1961, Lehman Brothers received $\$ 1,473,085$ for investment management services from The One Wilham Street Fund. This fee represented approxiinately seventy per cent of the total expenses of One William Strect for the year. [1961] The One Wulliam Street Fund, INc. ANN. REP.

The One William Street Fund recently offered to reduce its payments to Lehman Bros. by at least $\$ 125,000$ a year in order to settle a 1960 stockholder's suit charging the fund with paying excessive management fees to Lehman Bros. See Wall Street Journal, Feb. 28, 1962, p. 4, col. 4 (Pacific Coast ed.). "There were about sixty derivative suits pending in March involving thirty funds. May, Observations, 193 The Comomerctal and Financial Caronicle 968 (1961)." The Mutual Fund and Its Management Company: An Analysis of Business Incest, 71 YaLE L.J. 137 n.1 (1961). On the recent mutual fund bitigation, see Eisenberg \& Phillips, Mutual Fund Litigation-New Frontiers for the Investment Company Act, 62 Colum. L. REv. 73 (1962). 
recommends, that the underwriting be managed by Lehman Brothers; as manager he requests, and as director he accepts, a certain spread; as underwriter he solicits an order for a block of the new issue from Lehman Corporation that he, as a director of Lehman Corporation, votes to place. ${ }^{27}$

The directors of Lehman Corporation owe it a duty to disclose all information pertinent to its present and proposed investments. These same men owe a duty to the other corporations on whose boards they sit not to disclose inside information, especially to competitors. Yet, directors of the following competing corporations are also directors of Lehman Corporation: Ford Motor Company, General Motors Corporation, and Studebaker Corporation; Shell Oil Company and Standard Oil Company (Califormia); International Business Machine Corporation, Smith Corona Marchant Inc., Sperry Rand Corporation, and Underwood Corporation; Continental Airlines, Inc., Pan American World Airways, Inc., and Trans World Airlines, Inc. ${ }^{28}$

An impasse would seem to arise in the following hypothetical, but not improbable, situation. A Lehman partner through his directorship acquires confidential information from which he deduces that his corporation is a poor imvestınent risk and that the inarket value of its securities will be severely depressed when the news becomes public in a few days. As a director of One William Street, which owns a large block of shares, does he advise it to sell? As a director of Lehman Corporation, which plans to purchase a large block of shares, does he advise against the purchase? As investment counsellor to a charitable trust that checks with him prior to investing one million dollars in the corporation, does he remain silent?229

Lehman partners and Lehman Corporation directors have earned the respect of the financial community for their business ethics as well as for their financial expertise. Nevertheless, by facilitating the maxmium utilization of the financial acumen, managerial skill, and entrepreneurial ingenuity of these men, the economic system has created a serious structural problem. The centralization of inside information and financial power, and the consequent potential conflicts of interest, inhibit rather than foster allegiance to acceptable fiduciary standards. A real question arises whether one can ask or expect corporation insiders to remain unmoved by the constant temptation to procure large profits with minor breaches of incompatible fiduciary duties.

\section{III}

It is apparent that the problems posed in part II represent a danger to the investing public. In addition, the nnagnitude of the financial power involved indicates that some forn of regulation is desirable. Past and present financial machinations demonstrate that the self-restraint of corporate insiders is not always sufficient protection for the ordinary investor.

27 Lehman Bros. has acted as underwriter for, or a Lehman partner or a director of Lehman Corp. is also a director of, more than fifty per cent (both by number of companies and by value of securities held) of the companies represented in the Lehman Corp. portfolio. These figures are derived from [1961] Lemanan CoRP. ANN. Rep. and the Appendix.

28 See Appendix. The effect of the Lehman interlocking relationships on competition in commercial aviation has been the basis of administrative action and adjudication. See Lehman Brothers Interlocking Relationships Case, 15 C.A.B. 656 (1952), portion reviewed aff'd, Lehman v. CAB, 209 F.2d 289 (D.C. Cir. 1953), cert. denied, 347 U.S. 916 (1954) ; FULDA, COMPETITION IN THE REgULATED INDUSTRIES: Transportation 236-38 (1961).

29 As to SEC treatment of similar incompatible fiduciary duties, see generally Cady, Roberts \& Co., SEC Securities Exchange Act Release No. 6668 (Nov. 8, 1961), 75 HARv. L. REv. 1449 (1962); Comment, Broker Silence and Rule 10b-5: Expanding the Duty to Disclose, 71 YaLE L.J. 736 (1962). 
Past abuse is summarized in the Senate report on the hearings that led to the enactment of the Securities Exchange Act of 1934:30 "Among the most vicious practices unearthed at the hearings was the flagrant betrayal of their fiduciary duties by directors and officers of corporations who used their positions of trust and the confidential information which came to them in such positions to aid them in their market activities." 31 These early predatory practices were not perpetrated solely by patently disreputable operators. Rather, they were practiced by such ostensibly reliable men and institutions as Richard Whitney, President of the New York Stock Exchange and the brother of a Morgan partner; ${ }^{32}$ Albert $\mathrm{H}$. Wiggin and the Chase National Bank of which he was the chief executive officer; ${ }^{33}$ and Charles E. Mitchell and the National City Bank of which he was the chairman. ${ }^{34}$

Recent events suggest a similar disparity between legal maxims and business practice $^{35}$ if the self-dealing of the ex-president of the Chrysler Corporation, ${ }^{30}$ the Re and subsequent scandals on the American Stock Exchange, ${ }^{37}$ and, in a slightly different context, the price-fixing activities of the manufacturers of electrical

30 Hearings on Stock Exchange Practices Before the Senate Committee on Banking and Currency, 73rd Cong., 1st \& 2d Sess. (1933-1934). See also Pecora, Watr Street Under OATu (1939) (written by the committee's chief counsel). The abuses leading to the enactment of the Securities Exchange Act of 1934 are summarized in $\S 2$ of that act, 48 Stat. 881 (1934), 15 U.S.C. \$ 78b (1958). The best known general discussions from an earlier day are: BrandeIs, OTIIER People's Money, and How the Bankers Use It (1914); RIpley, MaIn Street and Wald Street (1927); Veblen, Absentee Ownership and Business Enterprise in Recent Times (1923). For material analyzing § 16(b), see note 1 supra.

31 S. Rep. No. 1455, 73d Cong., 2d Sess. 68 (1934).

32 See SEC, Report on Investigation In the Matter of Richard Whutney Pursuant to Section 21(a) of the Securities Exchange Act of 1934 (Nov. 1, 1938).

33 See Pecora, Wall Street Under OAth 131-88 (1939).

$34 I d$. at $70-130$.

35 The most rigorous standard to which a court can hold a fiduciary is set forth in a famous statement of Chief Justice Cardozo: "Many forms of conduct permissible in a workaday world for those acting at arm's length, are forbidden to those bound by fiduciary ties. A trustec is held to something stricter than the morals of the marketplace. Not honesty alone, but the punctilio of an honor the most sensitive, is then the standard of behaviour." Meinhard v. Salmon, 249 N.Y. $458,464,164$ N.E. 545,546 (1928).

36 "William Newberg resigned as firm's president; 'differences of opinion' on corporation policy noted," Wall Street Journal, July 1, 1960, p. 22, col. 2 ; "Disclosed William C. Newberg's resignation as president resulted from dispute over profits received from 'interests in' Chrysler suppliers; said Mr. Newberg to hand over 'profits in excess of $\$ 450,000$.' made from 'interests in vendor companies," "Id. July 22, 1960, p. 3, col. 1; "Discovered William Newberg, former president, owned half-imterest in two companies that supply Chrysler with car parts,"Id. July 29,1960, p. 3, col. 2; "Newberg case may spur stiffer S.T.C. rules on executives' interest in supplier firms," Ibid.; "William C. Newberg, former president, sued company, charging he was 'scapegoat' to hide self-dealing by others; firm called suit 'baseless,'" Id. Jan. 19, 1961, p. 2, col. 2; "Newberg charged in suit he was promised job as chairman of Studebaker-Packard Corp.," Id. Jan. 19, 1961, p. 2, col.4. Captions from The Wali Street Journal Index (19601961).

37 "American Stock Exchange revoked registration of stock speciahists J.E. and G. F. Re, following S.E.C. charges of violations of securities laws," Wall Street Journal, May 16, 1960, p. 8, col.2; "Editorial on casual attitude of American Stock Exchange officials towards upcoming S.E.C. investigation," Id. June 29, 1961, p. 10, col.1; "American Stock Exchange decided not to censure G. A. Re and G.F. Re; disclosed some data on meeting dealing with cxpelled specialist team," Id. July 7, 1961, p. 6, col. 4; "Guterma, gambling charges, misuse of Amex rules figured in McCormick resignation," Id. Dec. 14, 1961, p. 1, col. 4 ; "Special committee of members urged sweeping reforms, unit asked more firms be represented on board, stronger administration," Id. Dec. 22, 1961, p.3, col.1; "S.E.C. assailed Exchange for rules 
equipment ${ }^{38}$ can be taken as examples. The 1961 Report of the Securities and Exchange Commission states that more injunctions were sought and more convictions were obtained in 1961 than in any previous year. ${ }^{39}$

Equally significant is the attitude of business executives that profiting from the use of inside information is either not wrong or not very wrong. A recent survey of business executives posed the following hypothetical:

Imagine that you are a member of the board of directors of a large corporation. At a board meeting you learn of an impending merger with a smaller company which has had an unprofitable year, and whose stock is presently selling at a price so low that you are certain it will rise when news of the merger becomes public knowledge. ${ }^{40}$

Of the executives replying, forty-two per cent stated that they would purchase stock in the smaller company for themselves and sixty-one per cent replied that they thought the average executive would buy some for himself. ${ }^{41}$

The capacity of swindlers to achieve financial eminence, the belief of many executives that inside information, like capital gains, is merely one of the fruits of corporate success, and the presence of a gullible and speculative investing public ${ }^{42}$ poses a threat of abuse that has been noted by the financial community itself. One brokerage firm has sent its managers and registered representatives a bulletin advising them that:

[T] he warning flags are fiying, and it behooves everyone of you to recognize this signal and to conduct yourself accordingly. . . . Our network with busy wardroom offices provides a perfect workshop for manipulation of the securities market. Manipulation and "rigging" of markets is as old as our business. At the present time it is against the law.... We must carefully guard against being "used" by irresponsible and avaricious groups or.individuals of any kind.43

The number of past and present abuses of their positions by corporate insiders supports the proposition that effective regulation slrould be external. Moreover, the difficulty of proving that inside information was wrongfully used and the possibility that different judges will give different interpretations to the same facts seem to require that an objective, rather than a subjective, standard should

breakdown; criticized floor traders, specialists, four key men," Id. Jan. 8, 1962, p.3, col. 1. Captions from The WaII StreEt Journal Index (1960-1962).

On contemporary stock swimdles and swindlers, see Euster, Other Side of the Coin; Even in a Great Bull Market Some Investors Lose, Barrons, Aug. 31, 1959, p. 5; Little Mine that Wasn't, Forbes, Oct. 15, 1961, p. 16; Ruchti, Must the Butyer Beware?, Supervisory Management, Sept. 1958, p. 50; Turning Heat on Boiler Rooms, Business Week, Aug. 9, 1958, p. 54; Wall Street and SEC Trip Up Con Man Peddling Stocks for Nonexistent Company, Business Week, Aug. 13, 1960, p. 107; Wise \& Klaw, The Spoilers: The World of Lowell Birrell, Fortune, Nov. 1959, p.170; Wise, The World of A.L. Guterma, Fortune, Dec. 1959, p. 144.

38 See Smith, The Incredible Electrical Conspiracy, Fortune, April 1961, p.132; May 1961, p. 161.

30 See Wall Street Journal, Mar. 8, 1962, p.5, col. 3 (Pacific Coast ed.).

40 Baumhart, How Ethical Are Businessmen, Harv. Bus. Rev., July-Aug. 1961, p. 16.

$41 \mathrm{Ibid}$. Section 16(b) was enacted in order to "bring these practices into disrepute and encourage the voluntary maintenance of proper fiduciary standards ...." H.R. REP. No. 1383, 73d Cong., 2d Sess. 13 (1934). The survey suggests the need of more rigorous encouragement.

42 Keith Funston, president of the New York Stock Exchange, cautioned against "gullibility and greed," citing inexperienced investors buying highly speculative stocks. Wall Street Journal, Apr. 6, 1959, p. 5, col.1.

43 Quoted in Hearings on H.J. Res. 438 Before a Subcommittee on Commerce and Finance of the House Committee on Interstate and Foreign Commerce, 87th Cong., 1st Sess. 2 (1961). 
be employed. ${ }^{44}$ Finally, the concentration of financial power and insider information in investment banking firms, as well as their vulnerability to pervasive conflicts of interest, indicates that their activities are especially appropriate for such regulation. ${ }^{45}$

\section{CONCLUSION}

The circulation and use of inside information is an inevitable incident of the centralization of economic power and responsibility. However, urongful use of the information and power possessed by the men who operate the investment banking system can be inhibited without either frustrating the constructive economic functions they perform or unnecessarily restricting their financial freedom. Short swing speculative transactions by the insider or his associates in the securities of his corporation are a perfect vehicle for market manipulation and the betrayal of fiduciary duties. ${ }^{48}$ Yet these transactions further no constructive economic interest. ${ }^{47}$ The regulatory method adopted in section $16(\mathrm{~b})$ of removing the motivation to engage in such transactions by making insiders liable for profits realized on short swing speculative transactions in the securities of their corporations seems sound. But section 16(b) sliould be amended to relate its coverage to the facts of financial life.

It is therefore submitted that the statutory definition of "insider" should be amended to include those business associates of an insider who because of their financial relationship to him are also likely to learn the corporate secrets. This could be done by amending section 16(b) so that any director, officer, beneficial owner, partner, trustee or beneficiary of any corporation, partnership, or trust of which the insider is a director, officer, beneficial owner, partner, trustee or beneficiary, is an insider to the same extent as the insider if a significant amount of the business of the corporation, partnership, or trust involves acting as an underwriter, broker, dealer, banker, investment counsellor, management consultant, investing in securities for its own account, or any combination of the preceding. Since it is witlin the power of the insider to sever the relationship creating insider status, it seems fair to put the burden upon him either to sever the relationship or to convince the Securities and Excliange Commission that a particular speculative transaction or series of transactions deserves exemption from the operation of the amended section $16(\mathrm{~b})$. The public concern to minimize the effects of conflicts of interest would seem to outweigh the legitimate expectancies of men who profit from sliort swing speculation in the securities of corporations of which they or their close business associates are insiders.

James E. Crilly, III

44 See note 4 supra.

45 See note 14 supra.

46 See generally Pecora, Watl Street Under Oath (1939).

47 The effect on market liquidity of short swing speculative transactions by insiders in the securities of their corporations is too tenuous to overcome the strong public interest in discouraging such transactions. 
Corporation

CHEMICALS

Air Reduction Co.

American Potash \& Chem. Co.

Commercial Solvents Corp.

Diamond Alkali Co.

General Aniline \& Film Corp.

Harshaw Chem. Co.

ENIERTATMMENT

Paramount Pictures Corp.

Twentieth Century Fox Corp.

FINANCIAI

BANES

Bankers Trust Co. (New York)

Central Savings Bank of N.Y. City

Chase Manhattan Bank

Chemical Bank N.Y. Trust Co.

Connecticut Bank \& Trust Co.

Federal Reserve Bank of N.Y.

Irving Trust Co.

National City Bank of Cleveland

Sears Bank \& Trust Co.

Wells Fargo Bank-Am. Trust Co.

INSURANCE COMTPANIES

American Mut. Liab. Ins. Co.

Atlantic Mut. Ins. Co.

Connecticut Gen. Life Ins. Co.

Metropolitan Life Ins. Co. (N.Y.)

Mutual Life Ins. Co. of N.X.

Pacific Mut. Life Ins. Co. (L.A.)

Security Title Ins. Co.

INVESTMIENT COMTPANIES

Affiliated Fund Inc.

American Business Shares Inc.

General Am. Investors Co.

Lehman Corp.

The One William Street Fund, Inc.

Scudder Fund of Canada Ltd.

\section{APPENDIX}

\begin{tabular}{|c|c|c|c|}
\hline & & $\begin{array}{l}\text { PCrossmirs } \\
\text { Partners }\end{array}$ & $\begin{array}{l}\text { Herd }{ }^{2} \\
\text { Outside }\end{array}$ \\
\hline $\begin{array}{l}\text { AsSETS IN } \\
\text { THOUSANDS } \\
\text { OF DOLLARS } 1\end{array}$ & $\begin{array}{l}\text { Non- } \\
\text { Directors } \\
\text { of Lehman } \\
\text { Corp. }\end{array}$ & $\begin{array}{l}\text { Directors } \\
\text { of } \\
\text { Lehman } \\
\text { Corp. }\end{array}$ & $\begin{array}{c}\text { Directors } \\
\text { of } \\
\text { Lehman } \\
\text { Corp. }\end{array}$ \\
\hline
\end{tabular}

1

1

1

298,084

$3,063,837$

518,243

$10,051,937$

$5,046,859$

448,506

$2,199,650$

828,429

135,138

$2,842,379$

177,907

87,876

$2,232,223$

$17,941,244$

$2,761,885$

49,301

25,650

804,505

28,636

26,675

353,812

294,102

$57,744^{6}$
1

1

1

1

1

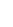

$2^{3}$

1

2

1

1

1

1

1

1

1

1

1

1

1

1

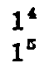

13

1

1 Assets are derived from Standard \& Poor's Corp., Standard Corporation Descriptions (as of April 1, 1962); Moody's Investors Service, Moodx's Bank \& Finance Manual (1961). 2 The directorships are derived from Don \& BRADSTREET, INC., 1962 MIrLION Dollar DirectorX; Standard \& PoOR's Corp., Poor's Register of Directors aNd Executtves: UNITEd States and Canada (1961).

3 In addition, one outside director of Lehman Corp. is a member of the finance committee.

4 Vice-President only.

5 Vice-President only.

6 Figures in Canadian dollars. 
CORPORATION

MISCELIANEOUS

American Express Co.

CIT Financial Corp.

Great Western Financial Corp.

Standard Financial Corp.

MANUFACTURING AND MAISCEILANEOUS AUTOMOTIVE MANUFACTURING

Ford Motor Co.

Fcrd Motor Co. of Canada Ltd.

Fruehauf Trailer Co.

General Motors Corp.

Studebaker Corp.

GENERAL MaNUEACTURING

Anchor-Hocking Glass Corp.

Brunswick Corp.

Caterpillar Tractor Co.

Emhart Mfg. Co.

FMC Corp.

Gar Wood Industries Inc.

Industrial Rayon Corp.

Midland Ross Corp.

U. S. Industries Inc.

MISCELLANEOUS

General Realty \& Utihties Corp.

Wells Fargo \& $\mathrm{Co}$.

Western Union Telegraph Co.

MERCHANDISING

STORES

Allied Stores Corp.

Associated Dry Goods Corp.

Bond Stores Inc.

Federated Dept. Stores Inc.

Gimbel Bros. Inc.

Gray Drug Stores Inc.

Interstate Dept. Stores Inc.

May Dept. Stores Co.

McCrory Corp.

Nieman Marcus Co.

Sears Roebuck \& Co.

MANUFACTURING CONSUAKER PRODUCTS

Chesebrough-Ponds Inc.

City Prods. Corp.

Ekco Prods. Corp.

General Cigar Co.

General Foods Corp.

International Silver Co.

Jewel Tea Co.

United Fruit Co.

Whirlpool Corp.
Assets IN

Thousands OP DOLLARS ${ }^{1}$

787,844

$2,364,839$

890,606

$\frac{110,871}{130,608}$

$3,756,804$

333,338

204,701

$7,841,902$

159,931

79,270

530,375

640,000

41,837

326,285

19,894

69,227

117,920

71,318

22,064

2,778

348,205

$\overline{14,565,849}$

286,717

178,954

62,901

365,470

219,118

14,196

37,555

419,985

282,138

22,682

$2,203,856$

62,275

137,622

67,079

49,708

549,414

52,868

135,084

337,641

220,577

$5,705,840$
DIRECTORSHUS HELD?

Lehman Partners Outside

Non- Directors Dircetors

Directors Directors of of

of Lehman Lchman Lehman

Corp. Corp. Corp.

2

1

1

1

1

1

1

$1 \quad 1$

1

1

$1^{7}$

1

1

I

1

1

1

1

2

1

1

1

1

2

1

1

1

1

1

1

1

1

1

1

1

1

1

1

7 Retired from Lehman Bros. 
CORPORATION

METAL \& MTNING

American Metal Climax Inc.

Flintkote Co.

Jones \& Laughlin Steel Corp.

North Am. Coal Corp.

OII \& GAS

American Climax Petroleum Corp."

Columbian Carbon Co.

Distillate Prod. Corp.

Halliburton $\mathrm{Co}$.

Kerr McGee Oil Indus. Inc.

Monterey Oil Co.

Mountaim Fuel Supply Co.

Murplyy Corp.

Quebec Natural Gas Corp.

Republic Natural Gas Co.

Sliell Oil Co.

Standard Oil Co. (Calif.)

Tidewater Oil Co.

Trans Canada Pipe Lines Ltd.

TXL Oil Corp.

packaging

Continental Can Co.

Maryland Cup Corp.

PAPER PRODUCTS

KVP Sutherland Paper Co.

Mead Corp.

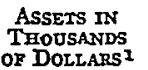

\begin{tabular}{ccc}
\multicolumn{2}{c}{ DirsctossmPs } & HeL ${ }^{2}$ \\
Lehman & Partners & Outside \\
Non- & Directors & Directors \\
Directors & of & of \\
of Lehman & Lehman & Lehman \\
Corp. & Corp. & Corp.
\end{tabular}

$\begin{array}{r}310,315 \\ 228,370 \\ 793,550 \\ 34,454 \\ \hline 1,366,689\end{array}$

1

1

1

1

1

1

88,940

159,713

219,016

(liquidating)

137,643

144,616

97,874

50,338

$1,885,344$

$2,782,283$

897,849

311,623

36,769

$6,812,008$

767,318

$\frac{23,265}{790,583}$

1

1

$\begin{array}{r}99,063 \\ 251,410 \\ \hline 350,473\end{array}$

1

1

RUBBER

Dayco Corp.

71,936

645,016

716,952

TECENOLOGICAL PRODUCTS BUSINESS MACEINES

International Busimess Mach. Corp. $\quad 1,535,366$

Smith Corona Marchant Inc.

Sperry Rand Corp.

Underwood Corp.

86,345

895,218

72,761

1

ELECTRONICS \& ELECTRICAL EQUIPAENT

Globe Union Inc.

Litton Indus. Inc.

Microwave Associates Inc.

31,709

119,004

7,653

815,503

$1,521,138$

Westingliouse Elec. Corp.

$\theta$ Affiliate of Maracaibo Oil Exploration Corp. 
CORPORATION

SPACE

Avco. Corp.

Bendix Corp.

PRECISION INSTRUMENTS

Beckman Instruments

Bulova Watch Co.

TEXTIIES

Cluett, Peabody \& Co.

Collins \& Aikman Corp.

Reeves Bros. Inc.

United Piece Dye Works Inc.

Van Raalte Co.

TRANSPORTATION

AIR

Continental Air Lines Inc.

Pan Am. World Airways Inc.

Trans World Airlines Inc.

AUTO

Fifth Ave. Coach Lines Inc.

Hertz Corp.

Hertz Am. Express Int'l Ltd. ${ }^{10}$

RAILROAD

Northern Pac. Ry. Co.

Southern Pac. Co.

MISCELIANEOUS

Air Express Int'l Hong Kong Ltd. ${ }^{\text {II }}$

U.S. Limes Inc.

180,169

$1,010,701$

$2,241,104$

585,734

525,311

85,720

148,550

35,394

39,869

6,312

25,928

190,239

(.............

\begin{tabular}{ccc}
\multicolumn{2}{c}{ Direcrorsurips } & HrLd \\
Lehman & Partners & Outside \\
Non- & Directors & Dircctors \\
Directors & of & of \\
of Lchman & Lehman & Lehman \\
Corp. & Corp. & Corp.
\end{tabular}

1

1

1

l

1

1

1

1

1

1

1

1

1

1

1

1

$4,859,404$

UTILITIES

Holyoke Water Power Co.

Middle So. Util. Inc.

Pacific Gas \& Elec. Co.

49,061

$1,024,477$

$3,214,461$

1

1

$4,287,999$

Total Assets Represented

$100,642,148$

Total Directorships

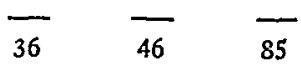

